\title{
階段式魚道のプール底面に設置した粗石が魚の 遡上特性に及ぼす影響 EFFECTS OF BOULDER OVER POOL BED ON MIGRATION RATE IN POOL-AND-WEIR FISHWAY
}

\author{
鬼束幸樹 1 ・秋山壽一郎 2 ・宍戸陽 3 ・高松周平 ${ }^{3}$ ・角田裕香 ${ }^{4}$ ・有須田朋子 5 \\ Kouki ONITSUKA, Juichiro AKIYAMA, Akira SHISHIDO, Shuhei TAKAMATSU, \\ Yuka KADOTA and Tomoko ARISUDA
1正会員 博(工) 九州工業大学大学院准教授＼cjkstart建設社会工学研究系（广804-8550 北九州市戸畑区仙水町1-1） 2フェロー会員 Ph.D. 九州工業大学大学院教授 建設社会工学研究系

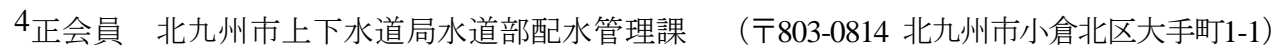
5正会員 清水建設侏)（广104-8340 東京都中央区京橋2-16-1）

\begin{abstract}
It is important to keep suitable area by boulder for fish in pool-and-weir fishway to make the migration rates high. In this study, migrating behaviors of oikawa by putting boulder on pool bed in pool-and-weir fishway was investigated. The migration rate of oikawa was obtained with the aid of two sets of digital video cameras. In addition, swimming position, swimming direction and migration route was investigated. It was found that migrating behaviors are difference between bed with boulder and flat bed. This is because oikawa swim slow flow area caused by boulder on pool bed. Further, swimming direction of oikawa in the case of flat bed comparatively match with each other, whereas that of it in the case of bed with boulder don't match.
\end{abstract}

Key Words : migration rate, Zacco Platypus, boulder on pool bed, pool-and-weir fishway

\section{1. はじめに}

河川にダムや堰が設置されると河川水位が縦断方向に 不連続となり，魚類の縦断移動が困難になる。サケやア ユなどの通し回遊魚にとって，不連続な水位落差の存在 は種の絶滅に直結するため, 魚道の併設が望まれる11,2).

魚道は，プールタイプ，水路タイプおよび閘門タイプ に大別され，プールタイプはさらに，階段式，バーチカ ルスロット式，アイスハーバー式，棚田式および替孔式 に分類される2),3). 以上のように様々な形式の魚道が提案 されているが，我が国の既設魚道の90\%以上を階段式魚 道が占める4),5)。中村5) はプールタイプ魚道を設計する上 で留意す心゙き点を次の5点としている，1)各プールの水 理条件が同一なこと，2)最大流速が魚の突進速度以下で あること，3)体高の2倍以上あるいは全高の1.2倍以上の 水深を確保すること，4)体長の $1 / 2$ 以上の経路幅を確保す ること，5)各プールに休息場所を確保することである.

上記の中で5)の必要性は次のように説明される。魚の 筋肉には普通筋と血合筋があり，緊急時には主として普
通筋を使用して突進速度(体長の約10倍程度)で遊泳する 6),7),8). ところが，普通筋を使用すると疲労が蓄積するた め，緊急度に応じて極力普通筋を使用しないように，魚 は普通筋と血合筋との使用割合を変化させる．普通筋を 僅かに使う遊泳速度は中間速度と呼ばれ，疲労が蓄積し ない血合筋のみを使う遊泳速度は維持速度(体長の約2-4 倍程度)と呼ばれる. 魚道内の流速が突進速度以下で あっても，中間速度以上で遊泳せざるを得ない流況では， 疲労が蓄積するため遡上が困難となる。したがって, プール内に休息場所を確保する必要がある.

一方，河川において魚類に休息場所を提供するものと して粗石が挙げられる. 小野田・萱場9は矢作川に設置 された矢作第二ダムから $0.7 \mathrm{~km}$ 下流の粗粒化した地点で, 自然状態および粒径約 $2 \mathrm{~mm}$ の砂を投入した両状態で魚類 調査を行った. その結果, 両者で優占魚種が異なること を解明した。田代ら ${ }^{10}$ は木曽川の支流の飯沼川を対象と して土砂還元前後の魚類調査を行い，粒径に応じて魚類 相が変化することを解明した．渡辺ら ${ }^{11)}$ は石狩川支流の 真駒内川を対象として，河道形態，河床形態，河岸状態 
および底生魚類の生息状況を比較した結果，巨碩や浮き 石によって創出された空隙をハナカジカが利用している ことを解明した。 原田ら ${ }^{12}$ は粗粒化した石碩河床におけ る魚の利用可能空間を定量的に算出した.

粗石を魚道に利用する研究も始められた，金子ら ${ }^{13)}$ よび高崎ら ${ }^{14}$ は多摩川の支流の秋川において，粗石付き の魚道およびアイスハーバー式魚道における魚の遡上調 查を行った. その結果，粗石の有無が遡上寸る魚種およ び尾数に影響を与えることを解明した．佐合ら $\left.{ }^{15}\right)$ は吉井 川の支流の金剛川に当時建設中であった大田原堰に設置 された階段式魚道の底面に, 粗石を設置しない場合, 粗 石を点在させた場合，および粗石を密に配置させた場合 における魚の遡上調査を行った，その結果，粗石を設置 しない場合，粗石を点在させた場合，および粗石を密に 配置させた場合の順に遡上率が増加することを解明した。 Santos et al. ${ }^{10}$ は粒径が $10 \mathrm{~cm}$ および $15 \mathrm{~cm}$ の粗石を底面に設 置した魚道で遡上実験を行った結果，粒径の大きな場合 の遡上時間が短くなることを示した. ただし，粗石が魚 道の河床に大量に堆積し, 流水断面積が著しく減少する 場合は，逆に遡上率が低下寸ることを青木ら ${ }^{177}$ は指摘し ている，以上のように，粗石の有無が遡上特性に影響を 及ぼすことは明らかになったが，その理由を解明するに は魚道内の流況と魚の挙動を把握しなければならない.

桜井ら ${ }^{18)}$ は魚道底面に碁盤目に設置された粗石周辺の 流況を観察し，粗石間を通過する流れが高速であるのに 対し, 粗石の上下流では低速な死水域が生じることを解 明した.八田ら ${ }^{199}$ は魚道底面の粗石周辺の乱流計測を行 い, 粗石背後で乱れ強度の極大領域が発生することを解

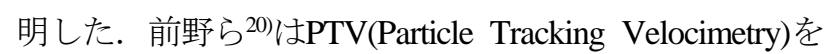
用いて粗石近傍の水平断面内における流速分布を計測し， 魚が休㴽可能な領域を推定した.

一方, 粗石を有する魚道内の魚の遊泳特性を解明し た研究はほとんどない，宮園・戸松21 は粗石を設置し た魚道内でのイワナの挙動をビデオ撮影した，その結 果, イワナは粗石前後を遡上経路として選択している ことが解明された。松木ら ${ }^{22}$ は直径が $5 \mathrm{~cm}$ の半球を魚 道底面に設置し, 流量を変化させた状態で平均体長が 93mmのウグイの挙動を観察した。 その結果, 遡上率 が高い場合ではウグイが粗石背後の低流速域で休款し ていることを確認した. しかし，粗石周辺の流速計測 を行い，魚の挙動と流速場との関係を定量的に解明し た研究はほとんどない。本研究は，階段式魚道の底面 に粗石を設置した場合および設置しない場合における 魚の遡上特性と水理量との関係を定量的に解明したも のである.

\section{2. 実験装置および実験条件}

図-1に実験に用いたグレーに塗装した木製の片側 切欠き付階段式魚道の模式図を示す。わが国におい

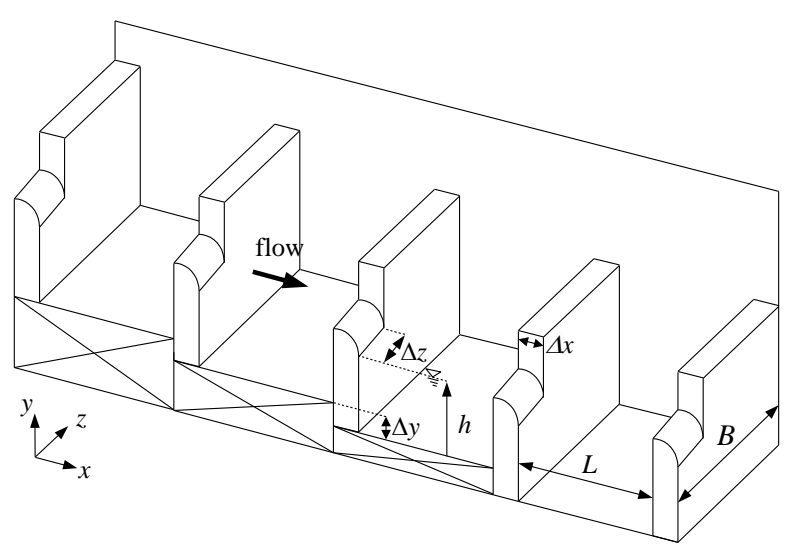

図-1 階段式魚道の概略図

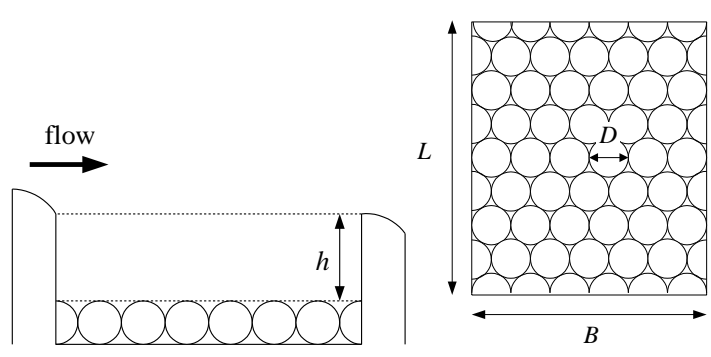

(a) 鉛直断面

(b) 水平断面

図-2 粗石の配置図

表-1 実験条件

\begin{tabular}{|c|c|c|c|c|c|}
\hline & $Q=1(1 / / \mathrm{s})$ & $Q=3(1 / \mathrm{s})$ & $Q=5(1 / \mathrm{s})$ & $Q=7(1 / \mathrm{s})$ & $Q=9(1 / \mathrm{s})$ \\
\hline Boulder on pool bed & BOQ1 & BOQ3 & BOQ5 & BOQ7 & BOQ9 \\
\hline Flat bed & FLQ1 & FLQ3 & FLQ5 & FLQ7 & FLQ9 \\
\hline
\end{tabular}

て，比較的設置率が高い魚道は片側切欠き付階段式魚道 である。したがって，本実験においても同魚道を採用し た. ただし，左岸側壁は撮影のため透明なアクリル

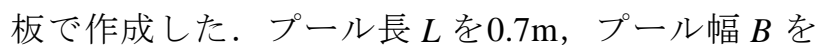
$0.6 \mathrm{~m}$, 隔壁厚 $\Delta x$ を $0.15 \mathrm{~m}$, 切欠き幅 $\Delta z$ を $0.12 \mathrm{~m}$, 落 差 $\Delta y$ を $0.15 \mathrm{~m}$ に設定した。また, 流下方向に $x$ 軸, 鋁直上向きに $y$ 軸，プール横断方向に $z$ 軸をとった. プール底面 $y=0$ から切欠き下端までの高さ $h$ を $0.2 \mathrm{~m}$ と した. 各諸元は小規模河川に設置される魚道と類似のス ケールである.

粗石形状として，四角柱や三角柱などが存在する が，本研究では基本形状であることおよび自然石に近

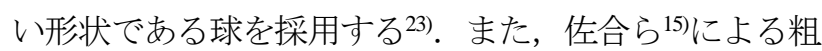
石の密度が高いほど遡上率が向上寸るとの指摘から, 最 密充填の配列方法を採用した. 図-2に示寸ように, 階段式魚道のプール底面に直径 $D=0.1 \mathrm{~m}$ の球を配 列した，表-1に示寸ように，底面に粗石がある場合と ない場合の2形態について, 流量 $Q$ を $1 \sim 9(1 / \mathrm{s})$ の範 囲で5通りに変化させた合計10ケースの実験を行っ た。ケース名は粗石を設置した場合を“粗石有り (Boulder on pool bed)”，設置していない場合を“粗 石無し(Flat bed)” とし, 流量の変化に基づき, 表-1 


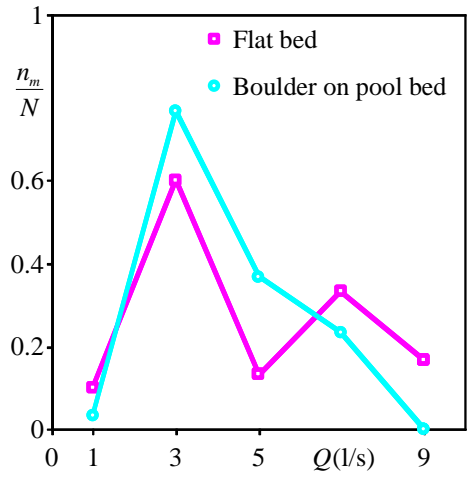

(a) 遡上率

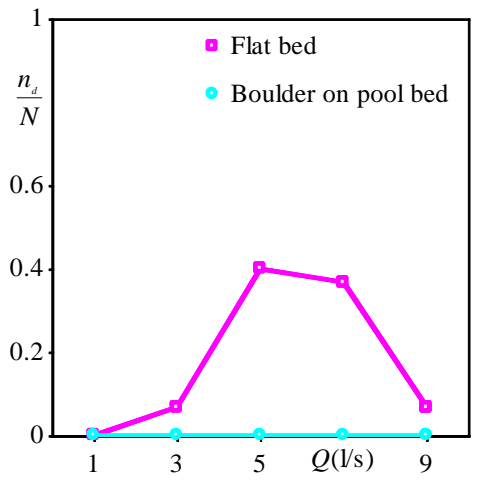

(b) 降下率

図-3 オイカワの遡上率・降下率

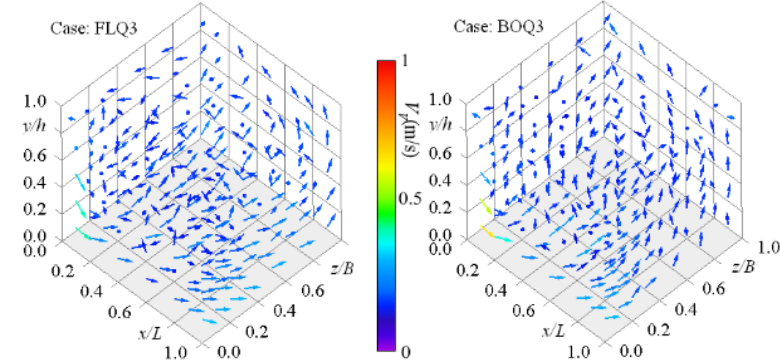

(a) $Q=3(\mathrm{I} / \mathrm{s})$ における流速ベクトル

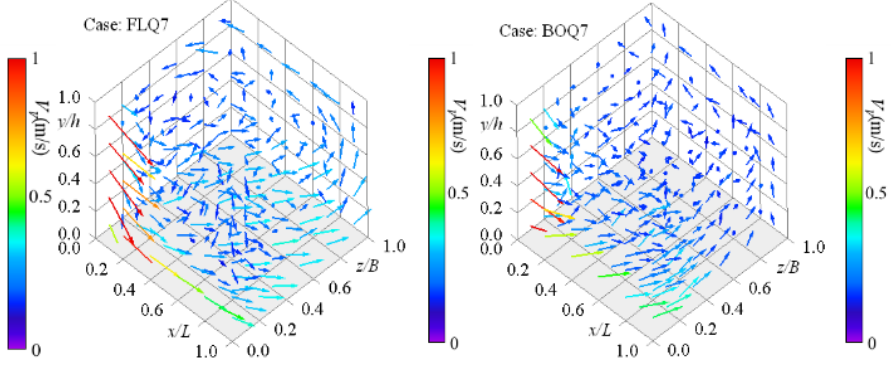

(b) $Q 7(\mathrm{I} / \mathrm{s})$ における流速ベクトル

図-4３次元合成流速ベクトル

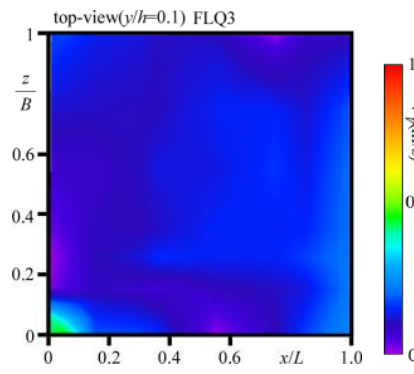

(a) $Q=3(\mathrm{I} / \mathrm{s})$ における流速コンター
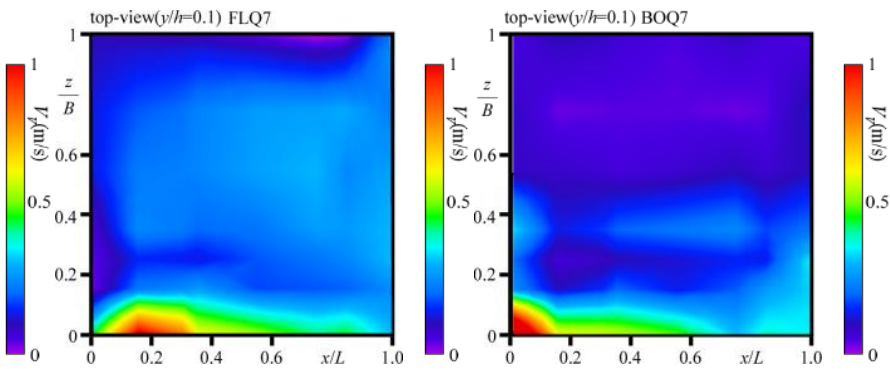

(b) Q7 $\quad \mathrm{I} / \mathrm{s})$ における流速コンター

図-5 $y / h=0.1$ における水平断面内の流速コンター

に示すケース名を命名した．粗石無しの場合は底面 を $y=0$ とし, 粗石有りの場合は粗石最上部を $y=0$ とした.

下流から2番目のプールに平均体長 $\overline{B_{L}}$ が $80 \mathrm{~mm}$ のオイ カワ(Zacco Platypus)を $N=30$ 尾放流し, 室温 $20^{\circ} \mathrm{C}$, 水温 $17^{\circ} \mathrm{C}$ 条件で実験を行った. 目視で定常を確認した後, 切欠きに設置した遡上防止用ネットを除去すると共に， プールの側壁および上部に設置した2台のカメラで30fps で20分間の撮影を行なった。撮影後，才イカワの遊泳位 置を $10 \mathrm{~s}$ ごとに解析すると共に，遡上数をカウントした. $x, y, z$ 軸方向にそれぞれ7，5，7点のメッシュで 構成される合計245点において，3次元電磁流速計を用い て流速 3 成分を $0.05 \mathrm{~s}$ 間隔で $25.6 \mathrm{~s}$ 計測した。計測後， $x$ ， $y, z$ 軸方向の時間平均流速 $U, V, W$ を算出し，合 成流速 $V_{V}=\sqrt{U^{2}+V^{2}+W^{2}}$ を得た。 なお，流速測定時 には魚道にオイカワを放流していない.

\section{3. 実験結果および考察}

\section{（1）オイカワの遡上率および降下率の比較}

遡上率および降下率を次式のように定義する。こ こで降下率は，魚道内における魚の滞留のしにくさ を表す。

$$
\text { 遡上率 }=\frac{\text { 遡上に成功した尾数 } n_{m}}{\text { 実験に用いた尾数 } N(=30)}
$$



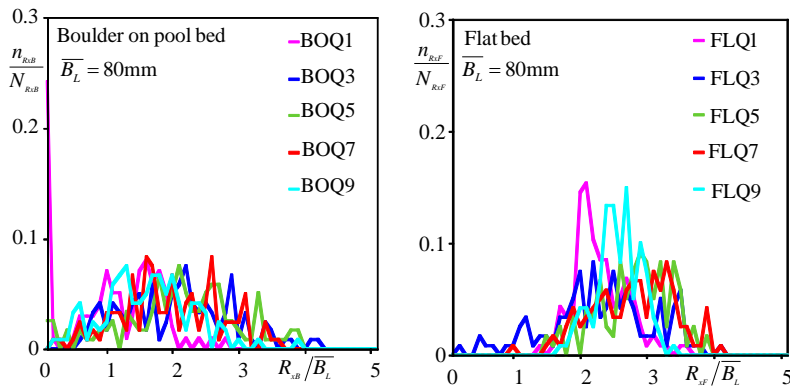

(a) $x$ 軸方向の魚群半径
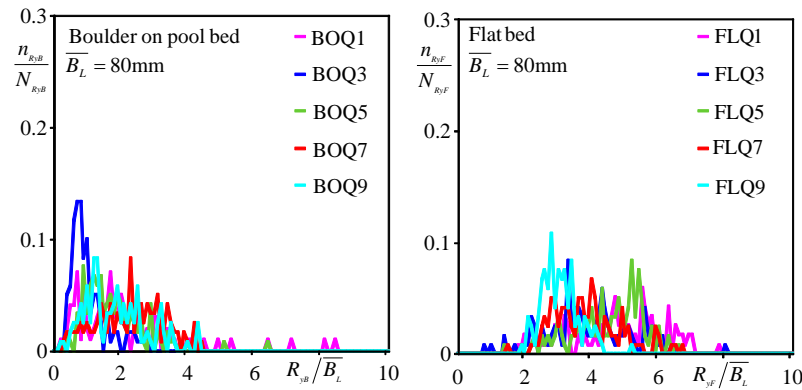

(b) $y$ 軸方向の魚群半径

図-6＼cjkstart各流量における魚群半径の頻度分布
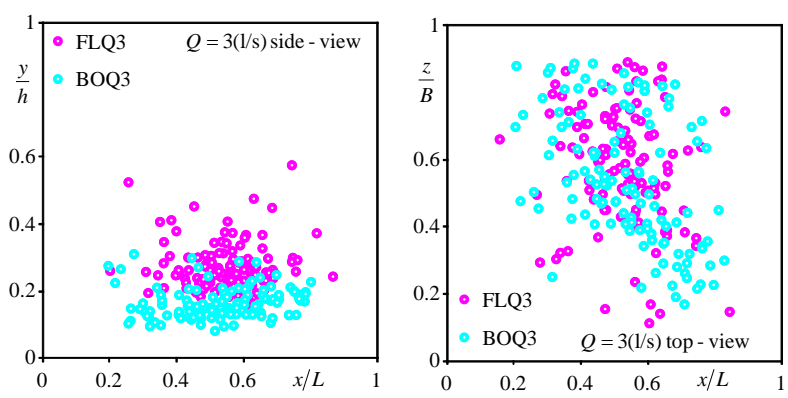

（a） $Q=3(\mathrm{I} / \mathrm{s})$ における魚群重心位置
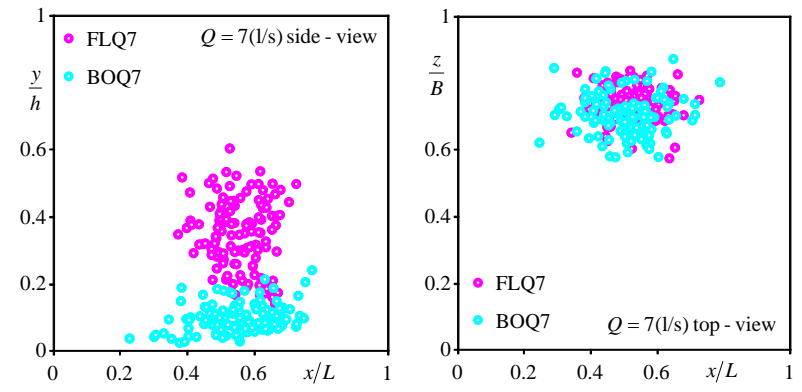

(b) $Q=7(\mathrm{l} / \mathrm{s})$ における魚群重心位置

図-7 鉛直断面および水平断面における魚群重心位置

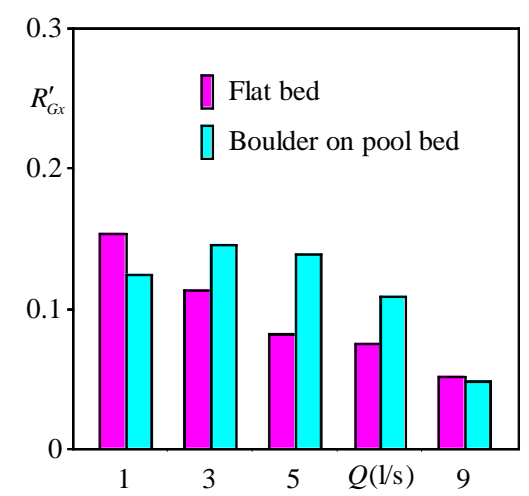

(a) $x$ 軸方向

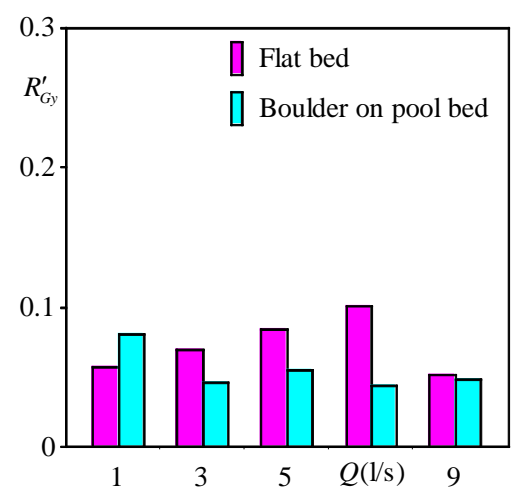

(b) $y$ 軸方向

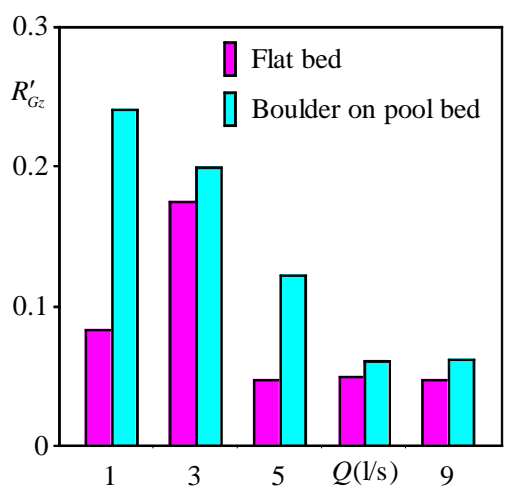

（c） $z$ 軸方向

図-8＼cjkstart魚群重心の広がりを表す標準偏差

降下率 $=\frac{\text { 降下した尾数 } n_{d}}{\text { 実験に用いた尾数 } N(=30)}$

図-3(a)に粗石有りおよび粗石無しにおける流量と才イ カワの遡上率 $n_{m} / N$ との関係を示す. 粗石の有無に関係 なく, $Q=3(1 / \mathrm{s})$ で遡上率が最大を示し, 流量の増加に 伴い遡上率が低下している.また, 遡上率が最大となる 流量付近では, 粗石無しよりも粗石有りの遡上率が高い.

図-3 (b) に粗石有りおよび粗石無しにおける流量 とオイカワの降下率 $n_{d} / N$ との関係を示す. 粗石無しの 場合の降下率が高いが，粗石有りの場合は降下せずに粗 石の隙間で停滞する個体が多く，降下率は全流量でゼロ であった。

\section{（2）プール内流況の比較}

図-4に粗石有りおよび粗石無しにおける $Q=3$, $7(1 / \mathrm{s})$ での3次元合成流速 $V_{V}$ をベクトル表示した. $Q=3(1 / \mathrm{s})$ に着目すると, 粗石の有無に関わらず上流 側切欠きからの落下流がプール底面付近まで潜り込 み，下流側隔壁に衝突することで左岸側水面付近に 上昇し, 循環流を形成していることが確認される. $Q=7(1 / \mathrm{s})$ で観察される循環流も流速が増加しているが, 類似の構造である.

図-5に粗石有りおよび粗石無しにおける $y / h=0.1$ での水平断面 $(x-z)$ の3 次元合成流速 $V_{V}$ コンターを $Q=3,7(1 / \mathrm{s})$ について示す. いずれのケースにおい ても，右岸側壁付近の流速が速いことがわかる。ま 
The number of the fish according to position $y / h$ in the case of boulder on pool bed
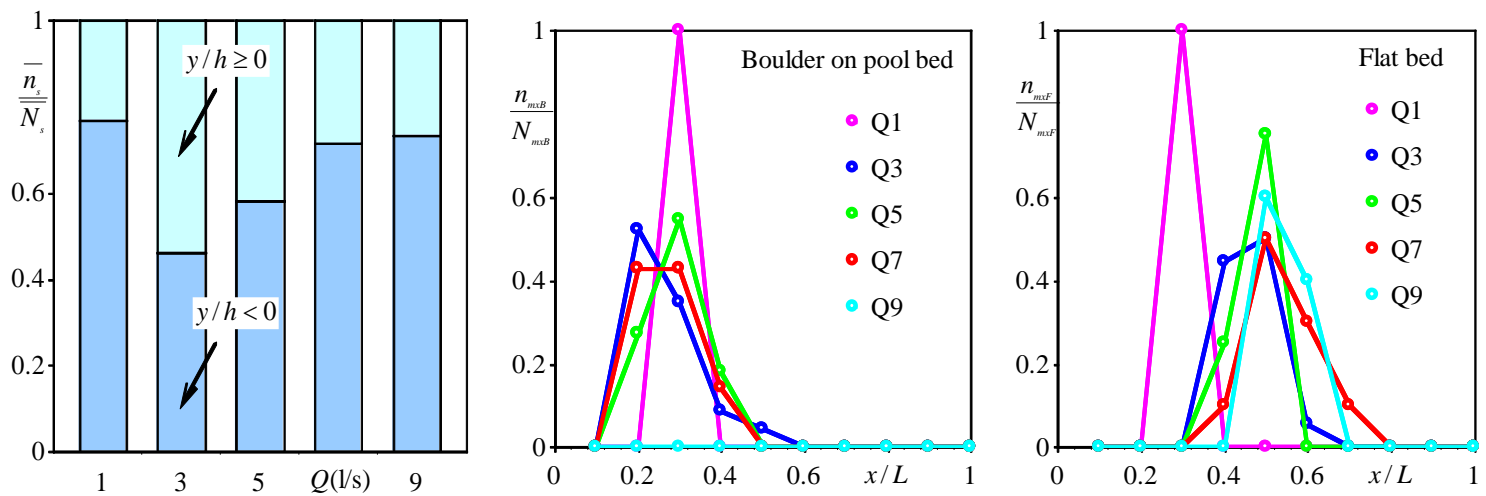

図-9＼cjkstart粗石付きプールにおける流量と $y$ 軸方向の遊泳位置との関係

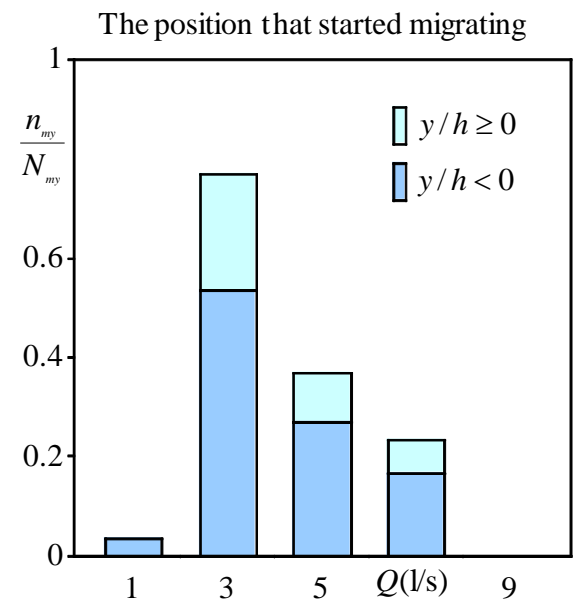

図-11 粗石付きプールにおける流量と $y$ 軸方向 の遡上開始位置との関係

た, 水平断面内の底面付近で粗石無しよりも粗石有 りの流速が低い.

\section{（3）粗石設置によるプール内の遊泳位置の変化}

図-6に各流量における $x, y$ 軸方向の魚群半径をそ れぞれ平均体長 $\overline{B_{L}}$ で除した值 $R_{x} / \overline{B_{L}}$ および $R_{y} / \overline{B_{L}}$ の 頻度分布を，粗石有りおよび粗石無しについて示寸 粗石有りの方が， $x$ 軸， $y$ 軸方向の魚群半径が減少して いることが確認できる。

図-7に流量 $Q=3,7(\mathrm{l} / \mathrm{s})$ の鉛直断面 $(x-y)$ および水 平断面 $(x-z)$ における $10 \mathrm{~s}$ ごとの魚群の重心位置を, 粗石有りおよび粗石無しについて示す. 流量の増加 に伴って魚群重心の範囲が狭くなっている．図-5を 参照すると, 流量の増加に伴い比較的流速の遅い場 所を選択的に魚が遊泳するために生じたと考えられ る. 鉛直断面 $(x-y)$ に着目すると, 粗石有りの方が 粗石無しの場合よりも重心が底面付近に接近してい る. また, 水平断面 $(x-z)$ においては, 底面に粗石 を設置した場合よりも設置していない場合の方が， 重心が集まる傾向にある.

図-8にx x軸，y軸および゙軸の魚群重心位置の標準偏差
$R_{G}^{\prime}$ を示す、 $x$ 軸， $z$ 軸では，粗石無しよりも粗石有りの 標準偏差が大きい，ところが，y軸では傾向が逆転して いる，これは，粗石を設置し底面付近の流速が低速なる ことで，オイカワが底面付近を選好して遊泳したためと 考えられる.

\section{（4）粗石設置による遊泳位置の変化}

図-9に粗石有りにおける，魚の重心位置の $y / h \geq 0$ お よび $y / h<0$ における存在確率の時間平均值 $\overline{n_{s}} / \overline{N_{s}}$ を示 す. $Q=1(1 / \mathrm{s})$ を除く $Q>3(1 / \mathrm{s})$ では, 流量の増加に伴 い $y / h<0$ における存在確率が増加している. これは, 流量の増加に伴いオイカワの粗石間の空隙の利用頻度が 増加したことを示している．図-5より底面付近では粗石 有りが粗石無しに比べて流速が減速されるため，遊泳に よる疲労を回避するために粗石の陌間を選択的に遊泳し たと考えられる. 小田ら ${ }^{24)}$, 古里・田中25), 冨永・市川 ${ }^{26}$ は粗石の上下流側の低流速領域が発生することを明らか にし，原田ら ${ }^{22}$ は石礫河床における魚の利用可能空間を 定量的に予測した．その結果，粗石近傍で魚が休钼可能 と推定した。本実験結果は上記の予測と整合している.

\section{（5）粗石設置によるプール内の遡上開始位置の変化}

図-10に粗石有りおよび粗石無しにおける， $x$ 軸方 向の遡上開始位置の頻度分布を示す．粗石無しよりも粗 石有りにおける遡上開始位置 $(x / L)$ が小さな值を示して おり，切欠きから近い位置から遡上を開始寸る傾向が増 加寸る. 遡上経路となる切り欠きは $x=0$ にあるため, 粗石無しよりも粗石有りの方が遡上経路が短くなる.

図-11に粗石有りの場合のオイカワの遡上開始位置の $y / h \geq 0$ および $y / h<0$ における各利用数 $n_{m y}$ を遡上数 $N_{m y}$ で除した $n_{m y} / N_{m y}$ を示す。遡上数がゼロの $Q=9(1 / \mathrm{s})$ を除くと, 遡上開始位置の全てあるいは多く が， $y / h<0$ となっている. したがって，底面に粗石を 設置すると，粗石を利用して遡上を開始するようになる と判断される. 


\section{4. おわりに}

本研究は, 階段式魚道の底面に設置した粗石が魚 の遡上特性に及ぼす影響を実験的に解明したもので ある. 本研究より得られた知見は以下の通りであり, 小規模河川に設置される魚道に対して有用な知見である と考えられる.

(1) 階段式魚道のプール内に粗石を設置すると，才 イカワの遊泳位置は底面付近に集中し，水平方 向に広がることが判明した。

（2）オイカワは流速の低下した粗石の隙間を選好し て遊泳する。

（3）プール内の底面に粗石を設置した場合，オイカ ワは粗石を利用して遡上していることが判明し た。 また，短い遡上経路で遡上可能になること が判明した。

謝辞: 本研究を実施するに当たり, 科学研究費補助 金基盤研究(C)26420500(代表 : 鬼束幸樹)の援助を受 けた。

\section{参考文献}

1）国土交通省河川局 : 魚がのぼりや寸い川づくりの手引き, 2005.

2)（財）ダム水源地環境整備センター編: 最新魚道の設計, 信山社サイテック, 1998.

3）鬼束幸樹: 魚道の流れて特性と魚の遡上特性との関係，なが れ, 第 31 巻, No.1, pp.19-28, 2012.

4) 井良沢道也, 石川芳治, 水山高久, 本間久枝 : 砂防におけ 万魚道の実態調查, 砂防学会誌, 第 44 巻, 第 6 号, pp.1220, 1992.

5) 中村俊六 : 魚道のはなし, 山海堂, pp.42-49, 1995.

6) Blaxter, J.H.S.: Swimming speeds of fish, FAO Conference on Fish Behaviour in Relation to Fishing Techniques and Tactics, pp.1-32, 1967.

7）鬼束幸樹，秋山壽一郎，山本晃義，渡邊拓也，脇健樹 : 河 川に生息する数魚種の突進速度に関する研究，土木学会論 文集 B, Vol.65, No.4, pp.296-307,2009.

8）泉完，菊地真弘，加藤幸，東信行 : 河川水を用いたヤマメ 稚魚の尾部の動きと遊泳速度, 農業農村工学会論文集, No.278, pp.99-107, 2012.

9）小野田幸生，萱場祐一 : 石磷河床への大量の覆砂が魚類生 息密度に及ぼす影響について，河川技術論文集，第 19 巻， pp.525-530, 2013.

10）田代喬，奥田千賀子，辻本哲郎：底生魚の生息場所からみた ダム下流の河床のアーマー化と土砂還元による機能の回復, 土木学会論文集 B1(水工学)，Vol.70, No.4,I_1321-I_1326,2014.

11) 渡辺恵三, 中村太士, 加村邦茂, 山田浩之, 渡邊康玄, 土屋進 : 河川改修が底生魚類の分布と生息環境におよぼす 影響, 応用生態工学, Vol.4, No.2, pp.133-146, 2001.
12) 原田守啓，小野田幸生，萱場祐一 : 粗粒化した石碩河床一 の土砂供給が遊泳性魚類の空間利用に及ぼす影響に関する 一考察，土木学会論文集 B1(水工学)，Vol.70，No.4，I_1339I_1344, 2014.

13）金子義明，和泉清，土屋十图，大竹義男 : 秋川における魚 道の水理特性と遡上効果, 水工学論文集, 第 42 巻, pp.265270, 1997.

14）高崎忠勝, 土屋十图, 大竹義男 : 秋川における複合型魚道 の効果, 河川技術に関する論文集, 第 5 巻, pp.165-170, 1999.

15) 佐合純造, 本多卓志, 大木孝志, 田中直也 : 大田原堰魚道 におけるアユの遡上実験報告, 水工学論文集, 第 42 巻, pp.493-498, 1998.

16) Santos, J.M., Branco, P.J., Silva, A.T., Katopodis, C., Pinheiro, A.N., Viseu, T. and Ferreira, M.T.: Effect of two flow regimes on the upstream movements of the Iberian barbel (Luciobarbus bocagei) in an experimental pool-type fishway, Journal of Applied Ichthyology, Vol.29, pp.425-430, 2013.

17) 青木宗之, 向井健朗, 㐘池裕太, 松木越 : 階段式魚道の プール内における砂の堆積が魚類の行動に及ぼす影響につ いて，土木学会論文集 B1(水工学)，Vol.71，No.4，I_1099I_1104, 2015.

18) 桜井力, 柏井条介, 佐々木國隆, 岡崎克美, 進藤邦雄, 岡 本俊策 : コンクリートブロックを用いた粗石式魚道の水理 および遡上特性, 水工学論文集, 第 44 巻, pp.1197-1202, 2000.

19）八田哲郎，鈴木辰規，村山久一，福井吉孝，荻原国宏 : 横 断勾配を持つ粗石付き緩斜路魚道について，河川技術に関 する論文集，第5巻, pp.147-152, 1999.

20) 前野詩朗, 名合宏之, 野村修治 : PTV 法に上る全断面魚道の 水理特性の検討, 水工学論文集, 第42巻, pp.481-486, 1998.

21）宮園正敏，戸松修 : 斜路式魚道における粗石の配置につい て, 砂防学会誌, Vol.56, No.1, pp.3-12, 2003.

22) 松木越, 青木宗之, 菊池裕太, 福井吉孝: 全断面粗石付魚 道の機能増進および修復について, 土木学会論文集 $\mathrm{B} 1$ (水 工学), Vol.71, No.4, I_1105-I_1110, 2015.

23）宮園正敏，高氏つぐみ，戸松修：粗石周辺の水理特性と溪 流魚の遊泳行動，砂防学会誌，Vol.57, No.5, pp.15-24, 2005.

24) 小田崇裕, 藤田一郎, 吉村英人, 岡西健史 : 粗面開水路乱 流の水面変動に及ぼす乱流洞構造の条件付き抽出に関する 研究，土木学会論文集 B1(水工学), Vol.70, No.4, I_823I_828, 2014.

25) 古里栄一, 田中規夫 : 大礫後部のマイクロハビタット特性 と遷移初期の水生昆虫動態, 土木学会論文集 B1(水工学),

Vol.70, No.4, I_1333-I_1338, 2014.

26）冨永晃宏，市川亜也佳 : 巨石群を底面に配置した開水路流 の抵抗特性評価，土木学会論文集 B1(水工学)，Vol.70, No.4, I_661-I_666, 2014. 